\title{
How Firms Cooperate in Business Groups? Evidence from Poland
}

\author{
Wioletta Mierzejewska' ${ }^{1}$ Patryk Dziurski²
}

Submitted: 27.07.20. Accepted: 26.03.21

\section{Abstract}

Purpose: The study aims to identify the main directions of intragroup cooperation, along with crucial areas of cooperation in business groups, and develops theoretical models of cooperation in a business group.

Methodology: The qualitative approach is applied in the study that is based on the cross-case analysis of four business groups operating in Poland.

Findings: Results indicate that business groups cooperate mainly vertically (cooperation between the core company and affiliates) in operations. Horizontal (among affiliates) and vertical cooperation in other areas - marketing, R\&D, finance, and human resources - are not so intense. The study enables us to propose a theoretical framework of cooperation models in business groups based on two dimensions - the direction of cooperation and the number of cooperation areas. It leads to the identification of four models: two-sided loose cooperation, two-sided tight cooperation, multi-sided loose cooperation, and multi-sided tight cooperation.

Implications: Identification of main directions of cooperation in business groups, along with areas of cooperation have implications for both researchers and managers. Findings of the study and the theoretical framework of cooperation models in business groups can be used as a basis for the further theoretical exploration of the organization and functioning of business groups in the economy and a strategic decision guideline for managers.

Originality: The literature focuses mainly on the interorganizational cooperation between dispersedly owned standalone entities. Studies on intraorganizational cooperation in business groups are limited. The study aims to provide a better understanding of cooperation between entities in business groups.

Keywords: business group, cooperation, area of cooperation, direction of cooperation.

$$
\text { JEL: M10, L14 }
$$

SGH Warsaw School of Economics, Al. Niepodległości 162, 02-554 Warsaw, Poland, e-mail: wioletta.mierzejewska@sgh.waw.pl; https:// orcid.org/0000-0001-9777-4376.

2 Corresponding author, SGH Warsaw School of Economics, Al. Niepodległości 162, 02-554 Warsaw, Poland, e-mail: patryk.dziurski@sgh. waw.pl; https://orcid.org/0000-0003-2132-8657. 


\section{Introduction}

Cooperation is recognized as a crucial success factor of organization growth and its role will become more and more important in the future (Teixeira and Leite, 2019). The management literature increasingly refers to the phenomenon of interorganizational cooperation between dispersedly owned standalone entitles in the form of strategic alliances (e.g. Todeva and Knoke, 2005; Lowensberg, 2010; Serrat, 2017; Shijaku, Larraza-Kintana, and Urtasun-Alonso, 2020), joint-ventures (e.g. Carr, Hawkins, and Westberg, 2017; Luo, 2002; Yeniyurt, and Carnovale, 2017), franchising (e.g. McDonnell, Beatson, and Huang, 2011; Terry and Di Lernia, 2013; Kremez et al., 2020), clusters (e.g. Najib and Kiminami, 2011; Schröder, 2014; Scheffi et al., 2019), consortium (e.g. Chan, 2004), and other, but it rarely focuses on the interfirm cooperation in business groups, especially on strategic relations between entities (Luo, 2005).

The main reason to create a business group is cooperation between entities (Trocki, 1998; Nogalski and Kreft, 2002), which are defined as networks of entities cooperating regularly over a long-time period (Powell and Smith-Doerr, 1994). Cooperation in a business group can reduce risks and costs and allows one to take advantage of the economics of scope, use a shared pool of skilled employees, and increase R\&D activity. Moreover, it gives easier access to the newest technology and new markets and creates higher value for clients (Contractor and Lorange, 2002). Some studies indicate that business groups can improve their competitive advantage by sharing resources among their entities, including intangible resources and technology (Chang and Hong, 2000). Moreover, cooperation in a business group allows entities to create a new, synergistic combination of resources and ideas. Business groups can also innovate to a greater extent as innovations are capital-intensive and often lack external financing sources.

Cooperation in a business group can occur between the core firm and affiliates (vertical cooperation) or between subsidiaries on the same or different levels in the hierarchy (horizontal cooperation). Cooperation between the parent company and affiliates is relatively well described, especially in the context of multinational corporations (Bartlett and Ghoshal, 1989; Martinez and Jarillo, 1989; Singh and Salwan, 2015). However, few studies focus on cooperation in business groups to provide empirical evidence related to the cooperation in the whole business group and on different levels in hierarchy. Holmes et al. (2015) and Colpan and Cuervo-Cazurra (2018) state that cooperation in a business group should be pursued in future research as its understanding would help to analyze their behaviors and formulate recommendations for managers. The lack of empirical studies on intraorganizational cooperation in business groups inspired us to conduct empirical research. Thus, the article aims to identify the main directions 
of intragroup cooperation and crucial areas of cooperation in business groups and develop theoretical models of cooperation in business groups.

The study contributes to management studies in two key and specific aspects. First, our study focuses on the cooperation in a whole business group, not only on cooperation between the core company and affiliates as most previous studies do. We identified the crucial cooperation areas and the direction of cooperation. Moreover, results inspired us to propose a framework of cooperation models in business groups. According to our knowledge, the framework is unique as it concentrates on cooperation in a whole business group. Second, our study covers different areas of cooperation and does not focus on one area of cooperation only.

The article is organized as follows. Section 1 presents the literature review on cooperation in business groups, along with the identification of main cooperation areas. Section 2 provides detailed information on data and the research method. Section 3 shows study results and describes cooperation practices in four business groups operating in Poland. Section 4 concludes the article with discussion and a theoretical framework of cooperation models in business groups.

\section{Literature Review}

The most often researched area in cooperation is the one that focuses on dispersedly owned standalone entities (Gebrekidan and Awuah, 2002; Alves, Segatto, and De-Carli, 2016; Pouwels and Koster, 2017), but the matter was also highlighted in organizations (Luo, 2007; Campbell, 2016). Cooperation can be also easily traced in business groups, in which entities are interdependent through ownership and non-ownership ties. Cooperation in a business group can occur with a different intensity, and it can be applied in different areas of operations. According to Li (2005) each entity in a business group has its own set of relations that link the entity with its external partners, like customers and suppliers and it is simultaneously embedded in internal business group network. Due to the high complexity of business groups, at least two types of cooperative relationships can be distinguished: interorganizational (with business and public entities outside a business group) and intraorganizational cooperation (between entities in a business group) (Gammelgaard et al., 2012). Thus, the article focuses on intraorganizational cooperation between entities in a business group.

Cooperation in a business group means joint activities undertaken by its entities, which can occur in different areas of operations and directions that engage the parent 
company and entities on different levels in hierarchy. According to Mahmood, Zhu, and Zaheer (2017), cooperation in a business group is facilitated through complex interfirm ties that promote resource and knowledge exchange. Cooperation in a business group is very often analyzed with reference to the relationship between the parent company and its subsidiaries (Luo, 2003; Monteneiro, 2008; Gnyawali, 2009). However, cooperation between affiliates can also occur, which is often described in the context of resource sharing (Kim, Shin, and Park, 2019). Thus, two directions of cooperation in a business group can be distinguished: vertical and horizontal (Bartlett and Ghoshal, 1990). The former means cooperation between the parent company and affiliates, while the latter refers to cooperation among affiliates.

Both horizontal and vertical cooperation can occur in different areas of operations. Cooperation in a business group most often applies to cross-selling, providing complementary products or services, using common infrastructure, joint purchase and distribution of final goods, sharing resources, including brands, customer bases, common investment, and financing policies (Cygler et al., 2012). Diversity of resources and capabilities among subunits creates opportunities for cooperation (Chang and Hong, 2000) as business groups benefit from tangible and intangible resource sharing (Kim, Shin, and Park, 2019). Thus, entities in a business group cooperate with each other in different areas. Luo (2005) finds that subunits in multinational corporations cooperate in four areas: technological, operational, organizational, and financial. Whereas Trocki (2004) identifies the following cooperation areas: marketing, human resources, operations (including technological cooperation), and finance. Cooperation in a business group can also be portrayed through its internal markets, and scholars most often identify internal markets for capital, human resources, supplies, and knowledge. Economics and finance research focuses mainly on internal capital markets, while the strategy-related field emphasizes internal markets for other resources (Holmes et al., 2015). Therefore, we claim that areas of cooperation in a business group are the following: operations and marketing, research and development (R\&D; including technological cooperation), human resources (HR), and finance. Moreover, we identify cooperation in knowledge transfer, but it occurs in every area of cooperation in a business group, between the core company and subsidiaries as well as among affiliates (Gupta and Govindarajan, 1986; Phelps and Fuller 2000; Schleimer and Riege 2009; Ho and Wang, 2015; Ishihara and Zolkiewski, 2017; Jeong, Chae, and Park, 2017; Gaur, Ma, and Ge, 2019; Głodowska, Maciejewski, and Wach 2019). 


\section{Cooperation in Operations and Marketing}

Operational cooperation focuses on new products or services development, and it may occur in every value chain function in a business group, including $R \& D$, purchase of supplies, production, sales, and distribution of final goods (Trocki, 2004). Internal cooperation includes a parent company and sister subsidiaries, which concerns the design of new production facilities, installation and initiation of new production facilities, mastering of new technologies, or design and launch of new products (Gurkov, 2015). Moreover, entities in a business group cooperate in developing, sharing, and exploiting operational resources and capabilities (Luo, 2005). Typically, they share global distribution channels, supply bases, quality control programs, productivity enhancement experiences, relationships building expertise, advertising and promotion skills, pricing strategies, customer financing policies, and warranty and service standards (Govindarajan and Gupta, 2001). Therefore, marketing cooperation results from operational cooperation that applies to product or service development, distribution, pricing strategies, and marketing communication. An important element of marketing cooperation is to create business group identity, which refers to visual (common visual identification originating from the core firm; brand and reputation), informative, and cultural identity (shared values) (Trocki, 2004).

The scope of operational cooperation in business groups depends on internal markets. On the one hand, entities in business groups cooperate and use the same infrastructure, resource base, brand, distribution channels, and supplies. On the other hand, the entities compete for suppliers, business partners, capital, and skilled managers. The literature confirms that business groups create and utilize internal markets with various benefits (Aluchna 2010; Park and Yuhn, 2012; Romanowska and Mierzejewska, 2015) such as the cost reduction of intragroup trade compared to arm's-length transactions - especially in markets that lack reliable information, weak rules of law, and with limited contract enforcement (Holmes et al., 2015), the ease of contract enforcement and coordination of joint activities, synergy effect and possibilities to share skilled employees (Khanna and Palepu, 1997; Khanna, 2000; Almeida, Chang, and Hwanki, 2015). Moreover, a study on Japanese keiretsu shows that intragroup trade provides vertical integration benefits without an increase in hierarchies that typically reduce flexibility (Dyer, 1996), which enables keiretsu to innovate and penetrate new markets (Bolton, Malmrose, and Ouchi, 1994). However, despite the many benefits of internal markets and intrafirm cooperation, they do not utilize them to a large extent due to geographical dispersion and the high efficiency of external markets (Mierzejewska and Romanowska, 2015). 


\section{Cooperation in Research and Development}

Research and development cooperation is important in business groups, which is very often seen as a component of operational cooperation. However, this study describes separately as it is very important in many industries and organizations (Dyduch 2019; Karbowski and Prokop 2019; Ferraris, Bogers, and Bresciani, 2020). Cooperation in R\&D in a business group refers to knowledge sharing on product and process innovation, and it aims to improve each other's competitive advantage in markets and benefit from economies of scope for their operations (Luo, 2005). Some research proves that cross-border R\&D cooperation in business groups leads to better performance by facilitating the integration of diverse knowledge (Seo, Kang, and Song, 2020). Li (2014) shows different R\&D models in multinational business groups: a satellite network, an upgraded satellite network, a loosely coupled network, and an integrated network. The former two models do not portray strong research and development cooperation, while the latter two emphasize joint R\&D operations. In the loosely coupled network model, R\&D activities are collocated in independent business entities in different regions. The last model is characterized by a great number of R\&D relations in a business group, which should flourish from organizational learning and increase the efficiency of operations worldwide. It can be the optimal pattern for configuring global R\&D activates but not for all business groups - as we should consider the economic situation of a country (Kaszowska-Mojsa, 2020) and regional context when analyzing R\&D cooperation in a business group (Giroud, Ha, and Yamin, 2014).

\section{Cooperation in Finance}

Another cooperation area in business groups is finance. In multinational business groups, financial cooperation means intra-corporate financing, including intragroup loans (Gopalan, Nanda, and Seru, 2007), dividend payouts (Gopalan, Nanda, and Seru, 2014), related-party transactions with the aim to transfer financial resources among affiliates (Jia, Shi, and Wang, 2013), transfer pricing, currency swaps, internal financial initiatives, sharing experience in managing cash flows, alleviating foreign exchange risks, hedging operating exposure, and formulating viable policies toward working capital management (Luo, 2005). Moreover, affiliates can share creditworthiness. For instance, financially stronger affiliates can guarantee loans for weaker subsidiaries, which enables the latter to take loans despite insufficient creditworthiness. Some business groups include banks so as to facilitate their internal flow of financial capital (Gerlach, 1992; Morck, Yavuz, and Yeung, 2011). Financial cooperation occurs mostly between a parent company and its affiliates, although cooperation among subsidiaries is also possible and depends on the support provided by the core company (Gurkov, 
2015). Similar to operational cooperation, cooperation in finance depends on the internal capital market, which is a common rationale for the formation and advantage-seeking of a business group (Holmes et al., 2015). Internal capital market enables affiliates to share financial resources (Perotti and Gelfer, 2001), funnel profits away from subsidiaries with few cash flow rights to those with greater cash flow rights (Chang, 2003), and support poorly performing subsidiaries (Kim, Hoskisson and Wan, 2004).

\section{Cooperation in Human Resources}

Cooperation in HR can bring synergy effects to the business group. Cooperation in HR allows a business group to effectively utilize its human capital, and it can occur at every stage in the human resource management process: human resources planning, training, career development, motivating, and transfers. Moreover, it may happen not only in entities but also among them. Cooperation in HR helps business groups to reduce exposure to a skilled labor shortage and provide flexibility to deploy employees to subsidiaries with the most promising prospects (Khanna and Palepu, 1997). Luo (2005) states that HR cooperation may be especially important in multinational business groups because it means sharing experience among managers from different affiliates. Moreover, local superior knowledge can be utilized worldwide (Głodowska, Maciejewski, and Wach, 2019). Thus, it seems that superior experience and experience in transferring strategic organizational practices is particularly important to multinational business groups (Kostova, 1999). However, not all business groups take the advantage of HR cooperation among subsidiaries. Gurkov (2016) proves that Russian subsidiaries only occasionally engage in cooperation with subsidiaries, and they are exposed to greater local embeddedness for HRM issues.

\section{Data and Methods}

Our study focused on cooperation in business groups in Poland. To meet the stated aims, we applied a qualitative approach to better examine cooperation in business groups, which agrees with the recommendation of Colpan and Cuervo-Cazurra (2018), who suggest using not only quantitative but also qualitative research methods. We used the case study method as it is a suitable means for studying new topics, along with developing and extending subject literature (Welch et al., 2013; Yin, 2018). The case study method enables researchers to retain the richness of results and the context of a business group (Hassett and Paavilainen-Mäntymäki, 2013). We used the multiple-case study to illustrate the cooperation in business groups in Poland, which is appropriate when the subject is complex and requires an in-depth analysis. Moreover, the 
multiple-case study opened the possibility for us to implement a cross-case comparison (Yin, 2018).

Based on purposeful sampling, we selected four information-rich illuminative case studies (Yin, 2018) from Poland that run operations in different industries, which allowed us to compare business groups from different business environments. We selected four case studies as recommended by Eisenhardt (1989) who indicates that a smaller number of cases can make theory generation more difficult.

Multiple data sources were used for the study, including interviews, annual firm reports, official websites, and business press. First, the approach allowed us to cross-check information and discover aspects that we could not have found through but one source of information.

Thus, we carried out four in-depth interviews with top managers employed in four different business groups. Respondents answered questions about the cooperation in their business group, including areas and directions of cooperation. Along with interviews, we selected appropriate documents, including annual reports and articles in the press, which were analyzed with a broader aim of increasing knowledge on the cooperation in selected business groups. From those readings, we derived further questions regarding cooperation in business groups for a follow-up data analysis. After gathering all materials and organizing them case by case, we studied and ordered the whole mass of text so as to provide an understanding of the intraorganizational cooperation in each business group. Then, we developed theoretical models.

Four different cases were deliberately chosen to illustrate different approaches to cooperation in business groups, which allowed us to investigate differences between cases in relation to theory. Below, we give an overview of the four business groups selected for the analysis.

Business Group 1 (BG1) operates in various industries, including cinema and film (cinema chains, film production and distribution), news articles (daily news articles and magazines), publishing (books, music albums, and DVDs), outdoor advertisement (out-of-home advertisings), the Internet (websites, video, mobile, and programmatic advertising), and radio (radio stations and music websites). BG1 operates mainly in the Polish market, and it consists of the core company and 24 affiliates.

Business Group 2 (BG2) operates in the construction industry that provides the rental and sale of construction scaffoldings and formworks, custom-made designs for form- 
work and scaffolding applications, construction materials and resources, along with concrete accessories, transport, equipment, and repair activities, including the sale and rental of construction equipment. BG2 operates mainly in Poland, Lithuania, Latvia, Kazakhstan, Romania, and Ukraine; it consists of the core company and four affiliates.

Business Group 3 (BG3) is the largest Polish IT company and one of the largest in Europe; in 2015 , BG3 generated $80 \%$ of the total revenue from state-of-the-art IT solutions. It runs operations in more than 50 countries worldwide, including most countries in Europe, Israel, the USA, Japan, Canada, Russia, and African countries. BG3 consists of more than 200 entities.

Business Group (BG4) is the leader on the Polish chemical market and one of the leading companies in Central Europe. It consists of manufacturing sites, along with trade and service businesses. The group operates in Poland and the European Union and consists of 36 entities, including the parent company, 24 operating in Poland and 11 operating abroad.

\section{Results}

This section provides a detailed description of the case study method inquiry into the cooperation of the four business groups in Poland. Cooperation in each business group is presented in parts, including a description of the cooperation in operations and marketing, R\&D, HR, and finance. Four case studies are presented as separate narratives. We will analyze the studies later, in the discussion section, through a cross-case comparison with theoretical implications.

\section{Case Study of Business Group 1}

\section{Cooperation in Operations and Marketing}

Operations of affiliates in the business group are complementary as they create the media group that operates in different parts of media industries. Operational cooperation occurs among publishing entities, printing companies, and advertising firms. In 2015 , intragroup trade amounted to $3.53 \%$ of total sales.

The area with the most intense cooperation lies in advertisement services offered to media houses. There is a centralized sales department for corporate clients, which is responsible for advertising sales on different media to media houses. Every project requires the involvement of different entities from the business group, depending on 
the content of the advertisement and the medium in which advertisements will appear. Moreover, cooperation among affiliates occurs on new projects, e.g. new television content.

Purchasing and aftersales operations are decentralized and performed by each subsidiary separately; marketing and promotional operations are also partly decentralized. BG1 has a vast variety of different brands, which is a result of its diversified operations. Each entity has its own brand and marketing strategy, yet the strategies must be approved by the core company. Nevertheless, the great autonomy of affiliates allows them to adjust marketing strategies to the needs of customers and best utilize employees' competences. The identity of the business group is dispersed.

\section{Cooperation in Research and Development}

Cooperation in R\&D - including technology transfer - does not occur in BG1 because of the nature of the business group. The business group does not run R\&D operations.

\section{Cooperation in Finance}

Business Group 1 has a centralized investment and financing policy. Investments are made by the executive board of the core company or with its approval. The parent company gives loans and financial guarantees to affiliates to support their operations. Subsidiaries do not give loans to other entities in the business group. There is also no internal financial institution that gives loans to affiliates.

There are common accounting standards in the business group: BG1 applies the International Financial Reporting Standards (IFRS). The group offers accounting and financial reporting services to affiliates, but not all affiliates use those services. Moreover, there is a cash pooling agreement that allows the business group to net off balances of various bank accounts.

\section{Cooperation in Human Resources}

Business Group 1 does not have common personnel policies as affiliates differ from each other, especially in terms of business activities and HR needs. The main difference lies in compensation systems, which are adjusted to job positions and departments. Moreover, each affiliate is responsible for recruiting and selecting employees, so they have their own HR departments. However, the recruitment and selection processes are centralized to an extent for the core company and affiliates located in Warsaw (the home of the parent company): the core company runs recruitment and selection processes for itself and key positions in subsidiaries located in Warsaw. Training is centralized 
to a relatively low extent: the core company offers soft skills training, which is delivered by the HR department, while job-related training is organized by managers of respective businesses with own budgets for training. Training is centralized to a small extent due to the great diversity of the business group. Business Group 1 believes that training decentralization enables it to meet employee needs better, favoring efficient employee induction.

Business Group 1 has a partial personal union, which means that members of the executive board from the core company are members of supervisory boards of its affiliates. This construct allows BG1 for better information flow and governance.

\section{Summary}

The key area of cooperation in the BG1 is operational cooperation, which focuses on providing advertisement services to media houses and can be characterized by the high intensity of vertical and horizontal cooperation, while cooperation between the core company and affiliates is more intense than among affiliates. In BG1, there also occurs cooperation in finance and HR. However, affiliates have relatively great autonomy due to huge product differentiation. Performance evaluation and the partial personal union between the parent company and affiliates are the main governance mechanisms in BG1. Some operations are centralized but they are limited to accounting, financial reporting, and training. The core company makes strategic decisions concerning the investment policy and growth of the whole business group; affiliates contribute to those decisions to a small extent.

\section{Case Study of Business Group 2}

\section{Cooperation in Operations and Marketing}

All entities in BG2 rent or sell construction scaffoldings and formworks, thus cooperation in the business group applies to construction projects and asset management. The core company coordinates and intermediates cooperation among entities in the business group; the parent company combines demands for assets from affiliates. There is also a shared services center (SSC) responsible for providing repair services available to all entities in the business group. Intragroup trade accounted for $7.45 \%$ of total sales at the time of the study.

Purchasing in BG2 is centralized, while sales and distribution are decentralized; it is the responsibility of respective subsidiaries as they operate in diverse geographical markets with different environmental conditions. 
Marketing operations are homogeneous in the business group. Entities in the business group use the same brand and there is a single visual identity dictated by the parent company due to low product differentiation (entities in the group offer similar products). The single brand enables easy identification of BG2 and increases its brand awareness. Moreover, homogeneous procedures and processes allow entities to build an informative identity.

\section{Cooperation in Research and Development}

Research and development operations in the business group are run by the core company as affiliates are relatively small-sized entities with limited resources. The parent company has a special team responsible for R\&D operations, including employees from affiliates, when needed. The Group operates in Poland but is part of a bigger business group that originated from Spain, which runs the main R\&D center, thus the R\&D team located in Poland cooperates intensively with the main team.

\section{Cooperation in Finance}

Business Group 2 has a centralized investment policy. All investments are planned by the core company based on assets and stocks analyses, which leads to more effective resource use and asset management. Moreover, financial cooperation includes loans and financial guarantees from the core company to affiliates, along with loans from subsidiaries to the parent company.

\section{Cooperation in Human Resources}

Business Group 2 has common personnel policies, including similar recruitment and selection policies, compensation systems, forms of employment, and employment structure. Business Group 2 introduces compensation regulations and pay scales with consideration of geographical differences among labor markets. The Group analyzes local labor markets and utilizes results to create compensation systems. Training in the business group is partially centralized, including training on new products and technologies. Centralized training is adjusted to job positions and geographical job markets. Moreover, every new employee partakes in induction training, which allows them to learn the organization. Entities in BG2 offer training as well. Cooperation in HR includes also employee transfers, but it mainly includes the delegation of employees from the core company to affiliates when they have problems or when there are important projects.

The core company manages and coordinates the business group by a partial personal union. Supervisory boards of affiliates consist of up to three members of the executive board from the core company. 


\section{Summary}

The main direction of cooperation in BG2 is vertical cooperation between the core company and affiliates, but there also occurs horizontal cooperation. However, horizontal cooperation is coordinated by the core company and it applies to asset management.

The crucial area of cooperation in BG2 is operations, which focuses on assets management. The nature of the business group leads to a homogeneous approach to operations both in the core company and subsidiaries. The business group has many common procedures and systems, the most important ones being personnel policies, marketing operations, including brand management, a centralized investment policy, and R\&D operations. Nevertheless, there functions a relatively flexible, semi-formal communication system. Moreover, employees from the affiliates are engaged in the strategy planning process for the whole business group. All these elements make BG2 appear as a homogenous and consistent system, which results from a high specialization of the group.

\section{Case Study of Business Group 3}

\section{Cooperation in Operations and Marketing}

All entities in the business group operate in the IT industry, including the core company. Business Group 3 offers various state-of-the-art IT products and services that enable them to benefit from the marketing and sales synergy as well as the cost synergy, which allows reducing costs due to economies of scale.

Cooperation in Business Group 3 is both vertical and horizontal, cooperation among affiliates often occurs without the participation of the core company. Operational cooperation mainly applies to resources, including subsidiaries' software and knowhow. Transactions between the parent company and subunits focus on selling products and services, but also office subletting. In 2015, intragroup trade accounted for $0.56 \%$ of total sales.

There is no cooperation in the area of procurement as each entity in the business group runs its own purchasing operations. Cooperation in sales and distribution occurs to some extent. On the one hand, affiliates can sell and distribute goods, but on the other hand, they can receive support from the core company.

Affiliates have great autonomy in marketing operations as they create marketing strategies independently, including decisions about products and pricing strategies. The visual identity of the business group is partially homogeneous, which means that the identity 
of some subsidiaries coincides with the identity of the core company. Business Group 3 engages in mergers and acquisitions, and the acquired entities very often keep their brands as they are well-known in their geographical markets. The Group also creates an informative identity through a brand book (a guide to new visualizations, colors, logos, etc.). However, affiliates do not need to follow the brand book. Moreover, there are attempts to build a cultural identity by communicating to subsidiaries values crucial for the core company.

\section{Cooperation in Research and Development}

Research and development operations in the Group focus on new product development and improving existing ones. Group entities very often create state-of-the-art IT solutions based on special orders, so specific departments are responsible for specific products. Research and development operations are mostly run by the core company, but some affiliates also conduct own research. Due to the great individualization of projects, R\&D operations are strongly decentralized. It is beneficial for both the Group and clients as the core company itself may be unable to develop state-of-the-art IT solutions based on the specific needs of clients; very often products are used locally. There is no main R\&D center for the whole Business Group.

\section{Cooperation in Finance}

The executive board of the core company sets strategic plans and aims for key investments, but there is no common investment policy. Affiliates have great autonomy in finance and investment. Investment decisions are made by both the executive board of the parent company and executive boards of subsidiaries, depending on the investment value.

If it agrees with the long-term strategy of the Business Group, well-performing affiliates support poorly performing subunits with loans, financial guarantees, or by increasing share equity.

Financial reporting is homogenous on the Business Group level. However, affiliates often use various accounting standards, including IFRS and US GAAP, which may differ from those used by the core company.

\section{Cooperation in Human Resources}

The core company tries to promote such values as engagement, professionalism, respect, and credibility, but personnel policies are decentralized as each affiliate has its own HR policies and procedures, including recruitment and selection processes, 
compensation systems, and training. There is no training center for the whole business group. The strong decentralization in HR cooperation results from the high geographical market diversification, which involves affiliates in diverse legal regulations they must follow.

Business Group 3 has a partial personal union. Members of the executive board and the supervisory board of the core company are members of executive boards and supervisory boards of its affiliates, but it does not apply to all subsidiaries, only to those crucial for the whole Group.

\section{Summary}

The key area of cooperation in Business Group 3 is operational cooperation, but cooperation among its entities is rare. Cooperation in the Group occurs when IT projects require know-how from other affiliates, and the cooperation can be both vertical and horizontal. Cooperation in other areas does not occur due to structural solutions. The Group operates as a federation with a great autonomy of its affiliates. The Group enables the use of local competences by affiliates and simultaneously generates a synergy effect on group level. The core company coordinates subsidiaries by setting strategic goals and controlling their achievement.

\section{Case Study of Business Group 4}

\section{Cooperation in Operations and Marketing}

The main area of BG4's operations is the soda segment. The core company sells soda, which is produced by affiliates, thus cooperation is mainly between the parent company and subsidiaries. Although horizontal cooperation among entities in the business group does occur, it is rare and applies to minor projects. Transactions between the core company and subsidiaries regard sales of products and services, including transport services. In 2015, intragroup trade amounted to $5.57 \%$ of total sales.

Procurement (negotiations and purchases) of key resources is centralized in BG4. Sales and distributions of products in the soda segment are also centralized as they are run by the core company, while other affiliates sell their goods themselves.

Marketing operations are centralized in the business group and marketing cooperation is intense, e.g. when there are changes in products, producing affiliates it is engaged in the whole process. Moreover, BG4 has a homogenous visual identity, which originates from the core company: it helps to increase brand awareness and build a sense of unity in the Group. 


\section{Cooperation in Research and Development}

Research and development operations are centralized in BG4: there is an affiliate responsible for research conducted for all entities in the business group who runs the operation with the support of other entities. The affiliate not only runs R\&D operations but also licensing trademarks to other entities. The centralization of R\&D operations allows BG4 to manage research more effectively.

\section{Cooperation in Finance}

The Group has a common investment policy set by the core company and based on the financial plan for Business Group 4. The investment policy includes affiliates' needs. Some investment projects are run by subsidiaries, but they are financed by the parent company. The centralization of investments enables the Group to raise external financing cheaper than if it was decentralized.

Cash flow management is centralized in the business group. There are special affiliates that run financial operations, including intragroup loans and leasing, money brokerage, issuing bonds and other financial instruments to private and corporate holders, along with the financial support of entities in the Group.

\section{Cooperation in Human Resources}

Business Group 4 implements common personnel policies in its entities, but it is hindered due to the high geographical market diversification of entities and different legal regulations on the markets. However, the core company encourages transparency in recruitment and selection processes to build employee engagement and implement job appraisal methods. There is a common compensation policy for members of executive boards of all affiliates in the Group, while compensation systems for lower-level job positions are decentralized, adjusting the compensation to local circumstances of subsidiaries. Training is centralized in BG4.

Interestingly, there is no personal union in BG4 as members of the executive board and the supervisory board of the core company are not members of executive boards and supervisory boards of affiliates.

\section{Summary}

The crucial area of cooperation in BG4 is operational cooperation, but it applies mainly to the soda segment. Cooperation also occurs in the area of marketing, HR, investment and financing policy, and R\&D. Thus, cooperation in the Group is relatively intense, especially between the core company and affiliates, due to the strong centralization of operations. Moreover, vertical cooperation results from the matrix structure of the 
Group. Managers in the core company are responsible for each area of operation of BG4 and supervise each investment directly. Thus, managers responsible for each investment are supervised by a manager from the core company and one from the affiliate company. All these procedures are settled in agreements. The Group is a system, in which respective affiliates work for the core company but at the same time receive support from the parent company and benefit from large-scale projects, the experience of other entities, and other synergy effects, which allows them to reduce costs.

\section{Discussion and Conclusion}

This section of the article presents a summary of case studies, a cross-case comparison, and a discussion. Business groups in the study differ from each other in areas and directions of cooperation. Table 1 presents the cross-case comparison of cooperation in business groups based on interviews and document analyses.

Table 1. Cross-case comparison of cooperation within business groups

\begin{tabular}{|c|c|c|c|c|c|c|}
\hline $\begin{array}{c}\text { Business } \\
\text { group }\end{array}$ & \multicolumn{3}{|c|}{ Area of cooperation within the business group } & \multicolumn{2}{|c|}{$\begin{array}{c}\text { Direction of cooperation } \\
\text { within the business group }\end{array}$} \\
\hline & marketing \\
and operations & R\&D & finance & HR & vertical & horizontal \\
\hline BG1 & high & low & medium & medium & high & medium \\
\hline BG2 & high & high & medium & high & high & low \\
\hline BG3 & medium & medium & low & low & medium & low \\
\hline BG4 & high & high & high & medium & high & low \\
\hline
\end{tabular}

Source: own elaboration.

The study shows that different patterns of cooperation can be found in the scrutinized business groups as they are organized differently and run businesses in different industries. However, the crucial area of cooperation in each business group is operational cooperation, which is a consequence of their organizational models. Core companies run operational activities (production and sales) and subsidiaries typically deliver support activities, thus fundamentally inclining toward operational cooperation. Cooperation in other areas (R\&D, finance, and HR) appears in different configurations depending on the organization model and the type of business activity. In two BG2 and BG4, all areas of cooperation showed medium to high intensity. However, 
in BG1 R\&D cooperation was non-existent, due to its type of business activity, while in BG3 this was the case of finance and HR cooperation, whose absence resulted from its organizational model.

Strong operational cooperation in other areas allows us to conclude that cooperation in business groups is a fundamental relation linking their entities. However, the intensity of cooperation differs, so we may assume that it is closely related to the business profile and organizational model of each business group. However, this should be verified in quantitative studies.

Our conclusion of the key role of cooperation between entities in a business group agrees with the network and resource approaches. According to the resource approach, business groups are perceived as a set of entities with different competences and resource profiles (Cerrato, 2006), but also as a platform for resource sharing (Chang and Hong, 2000; Hsieh, Yeh, and Chen, 2010). The main reason to create and run a business group is the desire to pursue a more effective allocation and use of resources, which is why cooperation is the main feature of business groups. In the network approach, business groups are considered to be a specific type of interorganizational network (Cuervo-Cazurra, 2006; Khanna and Rivkin, 2006), in which all units are bound together via various ties, i.e. common ownership, executives, products, financial, or interpersonal ties (Yiu et al., 2007). In such a network, the parent company acts as a central actor (broker) that controls resource flows and information exchange (Ćwik, 2013; Dmowska and Mikulska-Kowalczyk, 2019) by offering common administrative, financial, and managerial control and coordination (Yiu et al., 2007). Moreover, the network perspective implies the importance of cooperation between units, although due to the different organizations of each network, cooperation may vary from low to high intensity.

It was interesting for us to also examine the direction of cooperation in corporate groups. In most case studies, cooperation occurs mainly between the parent company and affiliates (vertical cooperation), which supports the view that business groups in the study are at the initial stage in the business group life cycle (Trocki, 2004), which agrees with other studies, thus proving that strong relations between the parent company and subsidiaries coincide with intensive support from the core company (Gurkov, 2015). Only BG3 can be portrayed differently as it rather is a federation of autonomous entities, in which affiliates cooperate with each other on IT projects without the involvement of the core company. However, the intensity of horizontal cooperation is low, and the intensity of vertical cooperation is medium. Business Group 1 has a different approach to cooperation altogether: it supports strong decentralization and autonomy of affiliates, 
which often initiates cooperation but with intense vertical cooperation. Vertical cooperation is profound for BG2 and BG4, in which horizontal cooperation is rare.

We expected the dominance of vertical over horizontal cooperation as business groups themselves can be characterized by the strong cooperation and governance by the core company. On the one hand, the structure of a business group can be compared to a dominated network (Child, Faulkner, and Tallman, 2005), in which the core company can be presented as the leader (Jasiński, 2012). Thus, according to the network approach, the role of the parent company as the central actor in a business group implies the domination of vertical cooperation (Yiu et al., 2007). Our study highlights that in the case of three business groups - BG1, BG2, and BG4 - the structure can be pursued in the form of the federative model (Andersson, Forsgren, and Holm, 2015) with different intensity of both horizontal and vertical cooperation. On the other hand, the BG3 case shows that both vertical and horizontal cooperation is relatively less intense due to the assumed business model.

As the conclusion of the study, we developed theoretical models of cooperation in a business group. The subject literature provides an insufficient number of frameworks of generic models of cooperation in a business group (Bartlett and Goshal, 1990). There are some frameworks that concern cooperation among dispersedly owned standalone entitles or cooperation only between the core company and affiliates. We propose such a framework that combines two dimensions: the number of cooperation areas in a business group and the direction of cooperation in a business group. Entities in a business group can cooperate in different areas such as operations, marketing, research and development, human resources, and finance. Thus, each dimension can be divided into low and high in the number of cooperation areas. The other dimension is the direction of cooperation, divided into bilateral and network cooperation. Bilateral cooperation means relations with selected entities in a business group - mostly only with the parent company - while network cooperation refers to simultaneous cooperation between the core company and affiliates and among subsidiaries. Table 2 presents the comprehensive framework of generic models of cooperation in a business group.

In the framework, we distinguish four generic models of cooperation in a business group. Considering the direction of cooperation, we have two-sided or multi-sided cooperation, which can be loose or tight depending on the number of cooperation areas. In the two-sided model, cooperation occurs mainly between the parent company and affiliates (vertical cooperation), but there may also appear horizontal cooperation (cooperation among affiliates). In the two-sided loose cooperation, affiliates are relatively autonomous and the parent company uses financial performance evaluation as 
the main governance mechanism. In the two-sided tight model, cooperation is intense and occurs in a great number of areas, mainly between the core company and subsidiaries. In turn, the multi-sided models refer to business groups that pursue both vertical and horizontal collaboration among all their entities. In the multi-sided loose model, cooperation occurs between different entities in a business group, but it only applies to a few areas. Business groups that can be named as loose multi-sided networks cooperate mainly in operations. In tight multi-sided cooperation, entities in a business group cooperate in many areas. Subsidiaries very often initiate cooperation that happens without the intermediation of the parent company. Our study allows us to conclude that business groups in Poland mostly apply the tight two-sided cooperation model characterized by a high number of cooperation areas and bilateral cooperation: mostly between the core company and affiliates. However, we may also identify another model. Our study shows that BG3 applies the loose two-sided cooperation model. In this model, cooperation is bilateral in few areas.

\title{
Table 2. Generic models of cooperation within a business group
}

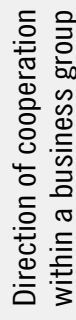

\author{
Network \\ cooperation \\ Multi-sided loose cooperation \\ Multi-sided tight cooperation \\ Bilateral \\ cooperation \\ Two-sided loose cooperation \\ Two-sided tight cooperation \\ Low number \\ High number \\ Number of cooperation areas within a business group
}

Source: own elaboration.

Although our research has reached its aims, it shows unavoidable limitations. There are limitations of the case study itself, which undermines the generalizability of results. However, our study is exploratory in nature and it should be empirically verified in different countries, industries, and business groups, including longitudinal analyses. Our data are subjective in nature as we asked one representative per firm about individual opinion. Further studies on intraorganizational cooperation in a business group are necessary to empirically verify the framework of generic models of cooperation in a business group. First, the framework should be verified with the case study method, showing different cooperation models in business groups and, second, with quantitative research methods. Future research should identify the factors that affect the 
implementation of different cooperation models in business groups. It seems that a diversification strategy may influence the choice of cooperation model as diversified business groups may not cooperate intensively and limit cooperation to respective areas of cooperation, such as finance and accounting. Other important factors may include business groups' origin, industry, age, and size. It would be interesting to answer the question which one of the cooperation models leads to the better financial performance of business groups and their affiliates.

\section{$\underline{\text { References }}$}

Almeida, H., Chang, S.K. and Hwanki, B.K. (2015). Internal Capital Markets in Business Groups: Evidence from the Asian Financial Crisis. The Journal of Finance, 70(6), 2539-2586. https://doi.org/10.1111/jofi.12309.

Aluchna, M. (2010). Kierunki rozwoju polskich grup kapitałowych. Perspektywa międzynarodowa. Warszawa: Oficyna Wydawnicza SGH.

Alves, F.S., Segatto, A.P. and De-Carli, E. (2016). Theoretical framework about relational capability on inter-organizational cooperation. Journal of Industrial Integration and Management, 1(04), 1650012. https://doi.org/10.1142/S2424862216500123.

Andersson, U., Forsgren, M. and Holm, U. (2015). Balancing subsidiary influence in the federative MNC: A business network view. In: Knowledge, Networks and Power (pp. 393-420). London: Palgrave Macmillan. https://doi.org/10.1057/palgrave.jibs.8400292.

Bartlett, C.A. and Ghoshal, S. (1989). Managing across borders. Boston, MA: Harvard Business School Press.

Bartlett, C.A. and Ghoshal, S. (1990). The multinational corporation as an interorganizational network. Academy of Management Review, 15(4), 603-626. https://doi.org/10.2307/258684.

Bolton, M.K., Malmrose, R. and Ouchi, W.G. (1994). The organization of innovation in the United States and Japan: Neoclassical and relational contracting. Journal of Management Studies, 31(5), 653-679. https://doi.org/10.1111/j.1467-6486.1994.tb00633.x.

Campbell, J.W. (2016). A collaboration-based model of work motivation and role ambiguity in public organizations. Public Performance \& Management Review, 39(3), 655-675.

Carr, J.B., Hawkins, C.V. and Westberg, D.E. (2017). An exploration of collaboration risk in joint ventures: perceptions of risk by local economic development officials. Economic Development Quarterly, 31(3), 210-227. https://doi.org/10.1177\%2F0891242417710325.

Cerrato, D. (2006). The multinational enterprise as an internal market system. International Business Review, 15(3), 253-277. https://doi.org/10.1016/j.ibusrev.2006.02.001.

Chan, W.W. (2004). International cooperation in higher education: Theory and practice. Journal of Studies in International Education, 8(1), 32-55. https://doi.org/10.1177/1028315303254429.

Chang, S.J. (2003). Ownership structure, expropriation, and performance of group-affiliated companies in Korea. Academy of Management Journal, 46(2), 238-253. https://oi.org/10.2307/30040617.

Chang, S.J. and Hong, J. (2000). Economic performance of group-affiliated companies in Korea: Intragroup resource sharing and internal business transactions. Academy of Management Journal, 43(3), 429-448. https://doi.org/10.2307/1556403.

Child, J., Faulkner, D. and Tallman, S.B. (2005). Cooperative strategy. Oxford: Oxford University Press. 
Chu, W. (2001). Contingency organizations and shared values: Multiple logics in managing diversification. Asia Pacific Journal of Management, 18, 83-99. https:/doi.org/10.1023/A:1010617323691.

Colpan, A.M. and Cuervo-Cazurra, A. (2018). Business groups as an organizational model. In: Oxford Research Encyclopedia of Business and Management. Oxford: Oxford University Press.

Contractor, F.J. and Lorange, P. (2002). Why should firms cooperate? The strategy and economics basis for cooperative ventures. In: F.J. Contractor and P. Lorange (eds.), Cooperative strategies in international business. Joint ventures and technology partnership between firms. Oxford: Pergamon.

Cuervo-Cazurra, A. (2006). Business groups and their types. Asia Pacific Journal of Management, 23(4), 419-437. https://doi.org/10.1007/s10490-006-9012-5.

Ćwik, K. (2013). Aspekty organizacji sieciowej a funkcjonowanie grupy kapitałowej. Organizacja i Zarzq̨dzanie, 4(24), 29-41.

Cygler, J., Aluchna, M., Marciszewska, E., Witek-Hajduk, M. and Materna, G. (2012). Kooperencja przedsiębiorstw w dobie globalizacji. Wyzwania strategiczne, uwarunkowania prawne. Warszawa: Wolters Kluwers Polska.

Dmowska, J. and Mikucka-Kowalczyk, M.A. (2019). Podstawowe założenia teorii organizacji sieciowych a aspekty funkcjonowania Grupy Kapitałowej KGHM. Economy and Customs and Legal Relations. Edition 9-10, February-April.

Dyduch, W. (2019). Entrepreneurial Strategy Stimulating Value Creation: Conceptual Findings and Some Empirical Tests. Entrepreneurial Business and Economics Review, 7(3), 65-82. https://doi.org/10.15678/EBER.2019.070304.

Dyer, J.H. (1996). Does governance matter? Keiretsu alliances and asset specificity as sources of Japanese competitive advantage. Organization Science, 7(6), 649-666. https://doi.org/10.1287/orsc.7.6.649.

Eisenhardt, K.M. (1989). Building theories from case study research. Academy of Management Review, 14(4), 532-550. https://doi.org/10.2307/258557.

Ferraris, A., Bogers, M., Bresciani, S. (2020). Subsidiary innovation performance: Balancing external knowledge sources and internal embeddedness. Journal of International Management, 26(4). https://doi.org/10.1016/j.intman.2020.100794.

Gammelgaard, J., McDonald, F., Stephan, A., Tüselmann, H. and Dörrenbächer, C. (2012). The impact of increases in subsidiary autonomy and network relationships on performance. International Business Review, 21(6), 1158-1172. https://doi.org/10.1016/j.ibusrev.2012.01.001.

Gaur, A.S., Ma, H. and Ge, B. (2019). MNC strategy, knowledge transfer context, and knowledge flow in MNEs. Journal of Knowledge Management, 23(9), 1885-1900. https://doi.org/10.1108/JKM-08-2018-0476.

Gerlach, M.L. (1992). Alliance capitalism: The social organization of Japanese business. Oakland: University of California Press.

Giroud, A., Ha, Y.J. and Yamin, M. (2014). Foreign subsidiaries' internal and external R\&D cooperation in South Korea: Explanatory factors and interaction. Asian Business \& Management, 13(3), 227-256. https://doi.org/10.1057/abm.2014.8.

Głodowska, A., Maciejewski, M. and Wach, K. (2019). How Entrepreneurial Orientation Stimulates Different Types of Knowledge in the Internationalisation Process of Firms from Poland? Entrepreneurial Business and Economics Review, 7(1), 61-73.

https://doi.org/10.15678/EBER.2019.070104.

Gnyawali, D., Singal, M. and Mu, S. (2009). Knowledge ties among subsidiaries in MNCs: A-multi-level conceptual model. Journal of International Management, 15, 387-400.

https://doi.org/10.1016/j.intman.2008.02.003. 
Gopalan, R., Nanda, V. and Seru, A. (2007). Affiliated firms and financial support: Evidence from Indian business groups. Journal of Financial Economics, 86(3), 759-795. https://doi.org/10.1016/j.jfineco.2006.09.008.

Gopalan, R., Nanda, V. and Seru, A. (2014). Internal capital market and dividend policies: Evidence from business groups. The Review of Financial Studies, 27(4), 1102-1142. https://doi.org/10.1093/rfs/hhu004.

Govindarajan, V. and Gupta, A.K. (2001). The quest for global dominance: Transforming global presence into global competitive advantage. San Francisco: Jossey-Bass Inc Pub.

Gupta, A.K. and Govindarajan, V. (1986). Resource sharing among SBUs: Strategic antecedents and administrative implications. Academy of Management Journal, 29(4), 695-714. https://doi.org/10.2307/255940.

Gurkov, I. (2015). Russian manufacturing subsidiaries of Western multinational corporations: Support from parents and cooperation with sister-subsidiaries. Journal of East-West Business, 21(3), 157-181. https://doi.org/10.1080/10669868.2015.1042619.

Gurkov, I. (2016). Human resource management in Russian manufacturing subsidiaries of multinational corporations. Post-Communist Economies, 28(3), 353-372. https://doi.org/10.1080/14631377.2016.1182735.

Hassett, M.E. and Paavilainen-Mäntymäki, E. (eds.) (2013). Handbook of longitudinal research methods in organisation and business studies. Cheltenham: Edward Elgar Publishing.

Ho, M.H.W., and Wang, F. (2015). Unpacking knowledge transfer and learning paradoxes in international strategic alliances: Contextual differences matter. International Business Review, 24(2), 287-297. https://doi.org/10.1016/j.ibusrev.2014.08.002.

Holmes, R.M., Hoskisson, R.E., Kim, H., Wan, W.P. and Holcomb, T.R. (2015). Business groups research: A comprehensive review, theoretical framework, and future research agenda. Conference article in: Academy of Management Annual Meeting Proceedings, August 2015.

Hsieh, T.J., Yeh, R.S. and Chen, Y.J. (2010). Business group characteristics and affiliated firm innovation: The case of Taiwan. Industrial Marketing Management, 39(4), 560-570. https://doi.org/10.1016/j.indmarman.2008.12.018.

Ishihara, H. and Zolkiewski, J. (2017). Effective knowledge transfer between the headquarters and a subsidiary in a MNC: the need for heeding capacity. Journal of Business \& Industrial Marketing. https://doi.org/10.1108/JBIM-06-2015-0109.

Jasiński, B. (2012). Sieci holdingowe. In: J. Niemczyk, E. Stańczyk-Hugiet, B. Jasiński (eds.), Sieci międzyorganizacyjne. Współczesne wyzwanie dla teorii i praktyki zarzq̨dzania. Warszawa: C.H. Beck.

Jeong, G.Y., Chae, M.S. and Park, B.I. (2017). Reverse knowledge transfer from subsidiaries to multinational companies: Focusing on factors affecting market knowledge transfer. Canadian Journal of Administrative Sciences/Revue Canadienne des Sciences de l'Administration, 34(3), 291-305. https://doi.org/10.1002/cjas.1366.

Jia, N., Shi, J. and Wang, Y. (2013). Coinsurance within business groups: Evidence from related party transactions in an emerging market. Management Science, 59(10), 2295-2313.

Karbowski, A., and Prokop, J. (2019). The Impact of Vertical R\&D Cooperation on Market Performance of Firms. Entrepreneurial Business and Economics Review, 7(4), 73-89. https://doi.org/10.15678/EBER.2019.070405.

Kaszowska-Mojsa, J. (2020). Innovation strategies of manufacturing companies during expansions and slowdowns. Entrepreneurial Business and Economics Review, 8(4), 47-66.

https://doi.org/10.15678/EBER.2020.080403. 
Khanna, T. and Palepu, K. (1997). Why focused strategies may be wrong for emerging markets. Harvard Business Review, 75(4), 41-43.

Khanna, T. and Rivkin, J.W. (2006). Interorganizational ties and business group boundaries: Evidence from an emerging economy. Organization Science, 17(3), 333-352.

https://doi.org/10.1287/orsc.1060.0188.

Khanna, T., (2000). Business groups and social welfare in emerging markets: existing evidence and unanswered questions. European Economic Review, 44(4-6), 48-61. https://doi.org/10.1016/S0014-2921(99)00059-8.

Kim, H., Hoskisson, R.E. and Wan, W.P. (2004). Power dependence, diversification strategy, and performance in keiretsu member firms. Strategic Management Journal, 25(7), 613-636. https://doi.org/10.1002/smj.395.

Kim, Y.C., Shin, T. and Park, S. (2019). Enhancing firm performance through intra-group managerial experience: Evidence from group-affiliated firms in Korea. Asia Pacific Journal of Management, 1-31. https://doi.org/10.1007/s10490-019-09671-3.

Kostova, T. (1999). Transnational transfer of strategic organizational practices: A contextual perspective. Academy of Management Review, 24(2), 308-324. https://doi.org/10.2307/259084.

Kremez, Z., Frazer, L., Quach, S. and Thaichon, P. (2020). Collaboration, communication, support, and relationships in the context of e-commerce within the franchising sector. Journal of Strategic Marketing, 1-23. https://doi.org/10.1080/0965254X.2020.1733051.

Li, Ch. (2014). Patterns of R\&D Configuration and Evolution in MNCs. DRUID Academy Conference in Rebild, Aalborg, Denmark on January 15-17.

Li, D., Ferreira, M.P. and Serra, F.R. (2009). Technology transfer within MNEs: Inter-subsidiary competition and cooperation. RAI-Revista de Administração e Inovação, 6(1), 139-158.

Li, L. (2005). The effects of trust and shared vision on inward knowledge transfer in subsidiaries' intra-and inter-organizational relationships. International Business Review, 14(1), 77-95. https://doi.org/10.1016/j.ibusrev.2004.12.005.

Lowensberg, D.A. (2010). A “new" view on "traditional” strategic alliances' formation paradigms. Management Decision, 48(7), 1090-1102. https://doi.org/10.1108/00251741011068798.

Luo, Y. (2002). Contract, cooperation, and performance in international joint ventures. Strategic Management Journal, 23(10), 903-919. https://doi.org/10.1002/smj.261.

Luo, Y. (2003). Market-seeking MNEs in an emerging market: How parent-subsidiary links shape overseas success. Journal of International Business Studies, 34, 290-309.

Luo, Y. (2005). Toward coopetition within a multinational enterprise: a perspective from foreign subsidiaries. Journal of World Business, 40(1), 71-90. https://doi.org/10.1016/j.jwb.2004.10.006.

Luo, Y. (2007). A coopetition perspective of global competition. Journal of World Business, 42(2), 129-144. https://doi.org/10.1016/j.jwb.2006.08.007.

Mahmood, I. P., Zhu, H. and Zaheer, A. (2017). Centralization of intragroup equity ties and performance of business group affiliates. Strategic Management Journal, 38(5), 1082-1100. https://doi.org/10.1002/smj.2542.

Martin, K. (2018). Poland upgraded to developed market status by FTSE Russell. Financial Times. Available at: https://www.ft.com/content/0e4eabc2-bfd1-11e8-8d55-54197280d3f7 (accessed: 25.09.2019).

Martinez, J. and Jarillo, J. (1989). The evolution of research on coordination mechanisms in multinational corporations. Journal of International Business Studies, 20, 489-514.

https://doi.org/10.1057/palgrave.jibs.8490370. 
McDonnell, J., Beatson, A. and Huang, C.H. (2011). Investigating relationships between relationship quality, customer loyalty and cooperation: An empirical study of convenience stores' franchise chain systems. Asia Pacific Journal of Marketing and Logistics, 23(3), 367-385. https://doi.org/10.1108/13555851111143268.

Monteiro, L.F., Arvidsson, N. and Birkinshaw, J. (2008). Knowledge flows within multinational corporations: Explaining subsidiary isolation and its performance implications. Organization Science, 19(1), 90-107.

Morck, R., Yavuz, M.D. and Yeung, B. (2011). Banking system control, capital allocation, and economy performance. Journal of Financial Economics, 100(2), 264-283. https://doi.org/10.1016/j.jfineco.2010.12.004.

Najib, M. and Kiminami, A. (2011). Innovation, cooperation and business performance. Journal of Agribusiness in Developing and Emerging Economies, 1(1), 75-96.

Nogalski, B. And Kreft, Z. (2002). Współdziałanie przedsiębiorstw w grupie kapitałowej. In: M. Romanowska and M. Trocki (eds.), Przedsiębiorstwo partnerskie. Warszawa: Difin.

Park, S.R. and Yuhn, K.H. (2012). Has the Korean chaebol model succeeded? Journal of Economic Studies, 39(2), 260-274.

Perotti, E.C. and Gelfer, S. (2001). Red barons or robber barons? Governance and investment in Russian financial-industrial groups. European Economic Review, 45(9), 1601-1617. https://doi.org/10.1016/S0014-2921(00)00097-0.

Pouwels, I. and Koster, F. (2017). Inter-organizational cooperation and organizational innovativeness. A comparative study. International Journal of Innovation Science, 9, 184-204. https://doi.org/10.1108/IJIS-01-2017-0003.

Powell, W.W. and Smith-Doerr, L. (1994). Networks and economic life. In: N.J. Smelser and R. Swedberg, The handbook of economic sociology. Princeton: Princeton University Press.

Romanowska, M. and Mierzejewska, W. (2015). Wewnętrzny rynek grupy kapitałowej jako substytut sieci biznesowych. Prace Naukowe Wałbrzyskiej Wyższej Szkoły Zarzq̨dzania i Przedsiębiorczości, 32, 333-344.

Schröder, C. (2014). Dynamics in ICT cooperation networks in selected German ICT clusters. International Economics and Economic Policy, 11(1-2), 197-230.

Seo, E., Kang, H. and Song, J. (2020). Blending talents for innovation: Team composition for cross-border R\&D collaboration within multinational corporations. Journal of International Business Studies, 51, 851-885. https://doi.org/10.1057/s41267-020-00331-z.

Serrat, O. (2017). Learning in strategic alliances. In: Knowledge solutions (pp. 639-647). Singapore: Springer.

Sheffi, Y., Saenz, M. J., Rivera, L. and Gligor, D. (2019). New forms of partnership: the role of logistics clusters in facilitating horizontal collaboration mechanisms. European Planning Studies, 27(5), 905-931. https://doi.org/10.1080/09654313.2019.1575797.

Shijaku, E., Larraza-Kintana, M. and Urtasun-Alonso, A. (2020). Network centrality and organizational aspirations: A behavioral interaction in the context of international strategic alliances. Journal of International Business Studies, 51, 813-828. https://doi.org/10.1057/s41267-018-0166-4.

Singh, N. and Salwan, P. (2015). Contribution of Parent Company in Growth of its Subsidiary in Emerging Markets: Case Study of Maruti Suzuki. Journal of Applied Business \& Economics, 17(1).

Teixeira, S. and Leite, E. (2019). Networks and Interorganizational Cooperation in Nature Tourism: A Case Study. Revista de turism - studii si cercetari in turism, 27.

Terry, A. and Di Lernia, C. (2013). Quasi-franchising: a new model for strategic business cooperation. In Th. Ehrmann, J. Windsperger, G. Cliquet, G. Hendrikse, Network Governance. Alliances, Cooperatives and Franchise Chains. Berlin: Springer. 
Todeva, E. and Knoke, D. (2005). Strategic alliances and models of collaboration. Management Decision, 43(1), 123-148.

Trocki, M. (1998). Zarządzanie grupą kapitałową. In: M. Romanowska, M. Trocki, B. Wawrzyniak (eds.), Grupy kapitałowe w Polsce. Warszawa: Difin.

Trocki, M. (2004). Grupy kapitałowe. Tworzenie i funkcjonowanie. Warszawa: Wydawnictwo Naukowe PWN.

Welch, C., Plakoyiannaki, E., Piekkari, R. and Paavilainen-Mäntymäki, E. (2013). Legitimizing diverse uses for qualitative research: A rhetorical analysis of two management journals. International Journal of Management Reviews, 15(2), 245-264. https://doi.org/10.1111/ijmr.12001.

Yeniyurt, S.,and Carnovale, S. (2017). Global supply network embeddedness and power: An analysis of international joint venture formations. International Business Review, 26(2), 203-213. https://doi.org/10.1111/ijmr.12001.

Yin, R. (2018). Case study research and applications: Design and methods. Los Angeles: Sage.

Yin, R.K. (2009). Case study research: Design and methods. Los Angeles: Sage.

Yiu, D. W., Lu, Y., Bruton, G.D. and Hoskisson, R.E. (2007). Business groups: An integrated model to focus future research. Journal of Management Studies, 44(8), 1551-1579.

https://doi.org/10.1111/j.1467-6486.2007.00735.x. 